\title{
Juridical Analysis on Government Regulation in Lieu of Law (PERPPU) Number 1 of 2017 on Access to Financial Information for Tax Purposes, Bank and Costumer Confidentiality
}

\author{
Satria Braja Hariandja \\ Ph.d in Law Program, Graduate School \\ University of Sumatera Utara \\ Medan, North Sumatra, Indonesia \\ suratbuatbraja@yahoo.co.id
}

\author{
Ningrum Sirait \\ Ph.d in Law Program, Graduate School \\ University of Sumatera Utara \\ Medan, North Sumatra,Indonesia \\ Ningrum.sirait@gmail.com
}

\begin{abstract}
World public awareness and compliance on tax payment obligations remain very low. Nowadays, there is a new agreement concerning Automatic Exchange of Financial Account Information. As the participant in the agreement, Indonesia is obliged to ratify the implementation of the agreement through Government Regulation in Lieu of Law (PERPPU) Number 1 of 2017 on Access to Financial Information for Tax Purposes.
\end{abstract}

There will be a consequence of the existence and implementation of the PERPPU to Customer Confidentiality, particularly on the customer's trust to the bank. When the data of the customer are made available and open, the customer's trust to the bank could be reduced. Consequently, customers may withdraw their money from the bank. While it is critical to the bank to maintain the trust, but compliance is another aspect that banks must enforce.

In order to find the solution, this study applied Juridical Normative approach method and focused on two elements: background and the consequences of the PERPPU Number 1 of 2017 on Access to Financial Information for Tax Purposes.

Keyword: banking information, confidentiality, tax purpose

\section{Introduction}

In carrying out the national development of the Unitary State of the Republic of Indonesia whose objective is to advance and prosper the entire Indonesian people equally and equitably, funding sourced from state revenues primarily derived from taxes is needed; consequently, granting wide access to the taxation authority to receive and obtain financial information for tax purposes is required to meet the needs of tax revenues. However, the public awareness to pay taxes is still very low. Besides, some taxpayers are dishonest in informing their actual income, so the amount of taxes they pay is not in accordance with the actual amount of their income when viewed from their total property.
Many taxpayers take the advantage of a bank to keep their fund for its confidentiality assurance, and for which the government cannot do anything. Basically, banks are required to keep confidential information about depositors and their deposits. [1] In its elucidation, it is stated "the information concerning the depositors is the information that should not be kept by the bank". Moreover, it is mentioned that if the bank's customers are both depositors and debtors, the bank also has to keep their information for their position as the depository customers.

Tax is a vital instrument for the state's revenue to finance its expenditures, both for routines and for national and economic development. However, to optimize tax collection, the tax authorities need to be equipped with the ability to collect various data and information related to taxation, so that they can quickly and effectively identify and analyze the risks on various taxpayers' non-compliance. [2] Bank secrecy is essential to any sound banking system. This begins with the relationship between the bank and its customers which requires the bank to keep all information related to its customers because they are unlikely to entrust their funds and financial affairs to the bank if it does not guarantee the confidentiality of their data. Therefore, this system plays an important role in protecting banking secrecy owned by a certain individual or a certain entity. [3]

Currently there is still limited access for Indonesian tax authorities to receive and obtain financial information regulated in taxes, banking, sharia banking, and capital markets laws and regulations, which may result in obstacles for the tax authorities to strengthen the taxation database in order to meet tax revenue requirements and maintain the sustainability of the effectiveness of tax amnesty policy. Meanwhile, Indonesia has been engaged in international agreements in the field of taxation in which it is obliged to 
fulfill the commitment of its participation in implementing the automatic exchange of financial account information and immediately formulate legislation at the level of the law on access to financial information for the benefit of taxation before 30 June 2017. Consequently, the government issued a Government Regulation in Lieu of Law (hereinafter called Perppu) to banking business related its Customer's privacy.

The issuance of the Perppu was motivated by the effort to categorize it as a prevailing positive law in Indonesia in order to avoid overlapping laws for the sake of legal certainty. In addition, the existence of this Perppu can have an impact for the existence of the banking world, so the effects of the existence of this Perppu need to be further studied.

\section{Research Methodology}

This is a normative juridical research focusing on studying the application of principles or norms of a positive law. [4] The data of this research are secondary data composed of (a) primary legal materials in the form of laws and regulation, and (b) secondary legal materials that include books and journals. The data were collected using literature reviews and document analysis. The data were analyzed using a conceptual approach and statue approach considering that the starting point of the research was to analyze the process of bank and customer protection related to the bank confidentiality since the issuance of Perppu for taxation purposes in accordance with the principles or norms of positive law that govern it.

Adopting the term proposed by Ronald Dworkin, this research is also called a doctrinal research, i.e. the research that analyzes both the law as it is written in the book and the law as it is decided by the judge through judicial process. [5]

\section{Discussion}

1. The Background of the Issuance of a Government Regulation in Lieu of Law Number 1 of 2017 on Access to Financial Information for Tax Purposes

a. The position of Government Regulation in Lieu of Law in Positive Law in Indonesia

In the Positive Law in Indonesia the provisions related to Government Regulation in Lieu of the Law are stipulated in the 1945 Constitution based on which the Perppu may be issued. In the case of urgen matters, the President shall be entitled to enact a government regulation in lieu of law. [3]
This is reaffirmed in Article 1 Paragraph 4 of Law Number 12 of 2011 on the Establishment of Legislation (UUPU) which states:

"Government Regulation in Lieu of Law is a Legislation stipulated by the President in relation to urgent matters"

The position of a Government Regulation in Lieu of Law in the hierarchy of legislation in Indonesia is regulated in Article 7 of the UUPU stating that the type and hierarchy of Legislations consist of: a. The 1945 Constitution of the State of the Republic of Indonesia; b. Decision of the People's Consultative Assembly; c. Law/Government Regulation in Lieu of Law; d. Government Regulation; e. Presidential Regulation; f. Provincial Regulations; and g. Local/Municipal Regulations;

Based on the hierarchy of Legislations, Government Regulation in Lieu of Law (Perppu) is equivalent to the Law and is under the Decision of the People's Consultative Assembly (MPR) and the 1945 Constitution. This means that Perppu shall not be contradictory to the Decision of MPR and the 1945 Constitution. However, Perppu can be used as a frame of reference or guidance by such lower Regulations like Government Regulation, Presidential Regulation and so on. However, Perppu might be in a lower position than Law when it has not been approved by the People's Representative Assembly (DPR). [7] The law has, so far, been established by the President through the approval of DPR, and under normal circumstances, or according to the amendment of the 1945 Constitution, the law shall be established by DPR and jointly approved by both DPR and the President, while Perppu is formed by the President without the approval of DPR due to urgent matters. [8]

The Perppu is temporary due to the urgent need and should be immediately submitted to DPR for its approval, i.e. at the upcoming session. If the Perpu is approved by DPR, then it will become a law; on the other hand, if the Perpu is not approved by DPR, then it will be revoked. Therefore, the hierarchy of Perppu is equal to Law, meaning that the function and the substance of Perppu are similar with the function and the substance of the Law. [9] Thus, when a Perppu has been approved by DPR and has been made a law, that is the moment when Perpu is seen as having equal status with a law. As a matter of fact, in the hierarchy, functions, and matters of legislations, both Perppu and law have the same position even if Perppu has not yet been approved by DPR. An example of a Perpu that has been approved by DPR and has been made a law is Law Number 15 of 2003 on Stipulation of Perppu Number 1 of 2002 on Combating Terrorism Crime, as the Law.

b. The Background of the Formulation of a Government Regulation in Lieu of Law Number 1 of 2017 on Access to Financial Information for Tax Purposes 
The government in its official release said there are some factors motivating the issuance of Government Regulation in Lieu of Law Number 1 of 2017 on Access to Financial Information for Taxation Purposes: [10] a. that in carrying out the national development of the Unitary State of the Republic of Indonesia whose objective is to advance and prosper the entire Indonesian people equally and equitably, funding sourced from state revenues primarily derived from taxes is needed; consequently, granting wide access to the taxation authority to receive and obtain financial information for tax purposes is required to meet the needs of tax revenues; b. that there is still limited access for Indonesian tax authorities to receive and obtain financial information regulated in taxes, banking, sharia banking, and capital markets laws and regulations, which may result in obstacles for the tax authorities to strengthen the taxation database in order to meet tax revenue requirements and maintain the sustainability of the effectiveness of tax amnesty policy; c. that Indonesia has been engaged in international agreements in the field of taxation in which it is obliged to fulfill the commitment of its participation in implementing the automatic exchange of financial account information and immediately formulate legislation at the level of a law on access to financial information for the benefit of taxation before 30 June 2017; d. that if Indonesia does not immediately fulfill the obligations within the prescribed time limit as referred to in point c, Indonesia is declared as a state that fails to meet its commitment of automatic exchange of financial account information, which will result in significant losses to Indonesia such as declining credibility of Indonesia as the G20 member, declining investor confidence, potentially disrupting the national economic stability, and possibly making Indonesia as the destination country for illegal funds placement;

Viewed from a global perspective, lack of adequate access to banking information for tax purposes may impede international co-operation which may contribute to unilateral action by a State tax authority to search for the information related to it. This can certainly disrupt the capital flows and financial transactions. [11]

2. The Impact of the Issuance of a Government Regulation in Lieu of Law Number 1 of 2017 on Access to Financial Information for Tax Purposes to Banks

Basically, a regulation can have a tremendous impact on stakeholders, meaning that the impact is related to the issuance of Government Regulation in Lieu of Law Number 1 of 2017 on Access to Financial Information for Tax Purposes.
A number of potential impacts arise from the policy of enactment of Perppu Number 1 of 2017 on Access to Financial Information for Tax Purposes. Through this regulation, the Directorate General of Taxes of the Ministry of Finance has a wide opportunity to access the financial information of customers who are the taxpayers.

Almost in every nation, there is bank confidentiality aimed at protecting their customers' data from the possibility of access by interested parties.

The Vice Chairperson of DPR of the Republic of Indonesia Taufik Kurniawan [12] said that the first impact is a consequence for banking business competition. The facility of easily accessing banking information to the international world can be used for an open competitive system. The consequences for banks that are not yet ready to compete, like Government owned banks that have no money market savings, are being more potential to lose in the competition,

The second impact is related to cyber banking management because of which the Perppu must be completed with a strong limitation in order not to be abused by certain parties. The enforcement of the Perppu is also expected to be supported by technological advancement aspects together with the good capability of banking's Information and Technology (IT) in order that the security in implementing this Perppu can be guaranteed. Through the implementation of this Perppu, the customers' data will become transparent, open, and in line with international provisions. Besides, their data will not be easily hacked and misused.

The third impact is that the principles of open management make banking activities open and transparent, so no one can hide them. This means that if the Directorate General of Taxes requires the financial account information of certain Bank Customers, then their financial account information will be known in detail. Therefore, customers can no longer hide their banking financial information. In other words, in this cultural transformation era, people cannot avoid the existing provisions, especially banking provisions.

Taufik hopes this policy does not necessarily make the community reluctant to save money in a bank. Therefore, it is the government's duty to strengthen this policy with a system capable of preventing hacking.

The negative impact of the issuance of Perppu Number 1 of 2017 on Access to Financial Information for Tax Purposes is that the community will be reluctant to go to banks and will save money at home. This is a challenge; in other words, it becomes a consequence when it can be avoided and best solution should be provided.

The Coordinating Minister for the Economy Darmin Nasution revealed that, in fact, long before the issuance of this Perppu, the Directorate General of Taxes had had an authority to access financial information for the taxation purposes. Nevertheless, the Directorate General of Taxes had to ask for permission from the Bank of Indonesia (BI), and the process of obtaining permission from BI was not such easy. The process often took long time. As a result, tax audits could be time consuming and had an impact on the investigation process. 
In addition, the financial institution had to report any financial account identified as a mandatory financial account to the Directorate General of Taxes. The report also included financial information for other tax purposes.

The content of the financial account report at least includes:

- the identity of the account holder

- the financial account number;

- the identity of financial services institutions;

- the balance or value of financial accounts; and

- the income associated with the financial account

The Directorate General of Taxes shall identify and verify the account. The Directorate General of Taxes shall also document the activities of identifying the customers' financial account. If the customers reject the identification process, the financial institution shall not serve them either for opening of a new account or any new transaction.

The scope relating to the Government Regulation in Lieu of Law Number 1 of 2017 on access to financial information for tax purposes is regulated in the Regulation of the Minister of Finance.

In the banking field, the provision related to the value of an individual account about which the bank financial services institution shall report to the bank is prevailing for those who have an account of Rp. 200,000,000.00 (two hundred million rupiahs) as stipulated in Article 19 paragraph (4) point $a$ and $b$ of Regulation of the Minister of Finance No. 70 of 2017, while an entity's financial account has no such restriction on the balance or value of its financial account. However, this provision has been subsequently revised by the Minister of Finance in which the value of an individual account that used to be Rp. 200,000,000.00 (two hundred million rupiahs) now becomes Rp. 1,000,000,000.00 (one billion rupiahs). [1] This means that this policy is intended to improve the database of the of Directorate General of Taxes to explore the true tax potential, to detect the risk of corporate fraud, to detect the risk of fraud committed by very rich individuals, and, as an instrument, to prevent the practice of double taxation. [14]

The increased transparency through the disclosure of financial information for the purposes of international taxation cooperation is a practice undertaken by more than 140 countries in the world. To safeguard the interests of Indonesia, it is necessary to build a culture of tax compliance by all levels of society. Only with strong tax revenue will Indonesia be able to build a just and prosperous society.

Indonesia decided to join AEOI; otherwise, Indonesia will be declared as a state that fails to meet its commitment of automatic exchange of financial account information. Such a predicate results in significant losses such as declining credibility of Indonesia as the G20 member, declining investor confidence, potentially disrupting the national economic stability, and possibly making Indonesia as the destination country for illegal funds placement.

The financial information contained in the report as referred to in Article 7 and Article 17 and the information and/or evidence or explanation as referred to in Article 15 and
Article 25 shall be used as the taxation database of the Directorate General of Taxes under the Regulation of the Minister of Finance Number 70 of 2017.

Any financial information and/or information and/or evidence or information as referred to in Paragraph (1) shall constitute information which shall be kept confidential in accordance with the provisions of laws and legislations and International Treaties.

The Minister of Finance and/or officers of the Ministry of Finance in performing duties related to the implementation of access and exchange of financial information for the taxation purposes cannot be prosecuted criminally or civil suitably sued.

The leader and/or officers of the Financial Services Authority who fulfill the obligation to submit the report as referred to in Article 3 Paragraph (1) point a, cannot be prosecuted criminally and/or civil suitably sued.

The management and/or employees of financial services institutions, the management and/or employees of other financial institutions, and the management and/or employees of other entities as referred to in Article 2 Paragraph (1), who: a. do not submit the report as referred to in Article 2 Paragraph (2); b. do not implement the proper account identification procedures as referred to in Article 2 Paragraph (4); and/or c. do not provide information and/or evidence or explanation as referred to in Article 4 Paragraph (2) shall be punished with a maximum of 1 (one) year imprisonment or a fine of not more than $\mathrm{Rp} 1,000,000,000.00$ (one billion rupiahs). (Article 7 and 8 of Government Regulation in Lieu of Law Number 1 of 2017 on Access to Financial Information for Tax Purposes).

Financial services institutions, other financial services institutions, and other entities as referred to in Article 2 Paragraph (1), which: a. do not submit the report as referred to in Article 2 Paragraph (2); b. do not carry out the proper procedure of financial account identification properly as referred to in Article 2 Paragraph (4); and/or c. do not provide information and/or evidence or explanation as referred to in Article 4 Paragraph (2), shall be fined a maximum of Rp1,000,000,000.00 (one billion rupiahs).

Anyone who makes a false statement or hides or deducts the actual information from the information that must be submitted in the report as referred to in Article 2 Paragraph (2) shall be subject to a maximum of 1 (one) year imprisonment or a maximum fine of Rp1,000,000,000.00 (one billion rupiahs). (Government Regulation in Lieu of Law Number 1 of 2017 on access to financial account information for the taxation purposes.)

\section{Conclusions}

1. The background of the formulation of Government Regulation in Lieu of Law (Perppu) Number 1 of 2017 on Access to Financial Account Information for the Tax Purposes is mentioned in the government official release: a. that in carrying out the national development of the Unitary State of the Republic of Indonesia whose objective 
is to advance and prosper the entire Indonesian people equally and equitably, funding sourced from state revenues primarily derived from taxes is needed; consequently, granting wide access to the taxation authority to receive and obtain financial information for tax purposes is required to meet the needs of tax revenues; $b$. that there is still a limited access for Indonesian tax authorities to receive and obtain financial information regulated in taxes, banking, sharia banking, and capital markets laws and regulations, which may result in obstacles for the tax authorities to strengthen the taxation database in order to meet tax revenue requirements and maintain the sustainability of the effectiveness of tax amnesty policy; c. that Indonesia has been engaged in international agreements in the field of taxation in which it is obliged to fulfill the commitment of its participation in implementing the automatic exchange of financial account information and immediately formulate legislation at the level of a law on access to financial information for the benefit of taxation before 30 June 2017; d. that if Indonesia does not immediately fulfill the obligations within the prescribed time limit as referred to in point c, Indonesia is declared as a state that fails to meet its commitment of automatic exchange of financial account information, which will result in significant losses to Indonesia such as declining credibility of Indonesia as the G20 member, declining investor confidence, potentially disrupting the national economic stability, and possibly making Indonesia as the destination country for illegal fund placement.

2. The impact of the issuance of Perppu Number 1 of 2017 on Access to Financial Information for Tax Purposes includes (i) a consequence for banking business competition. The facility of easily accessing banking information to the international world can be used for an open competitive system. The consequences for banks that are not yet ready to compete, like government owned banks that have no money market savings, are being more potential to lose in the competition; (ii) a cyber banking management. Perppu must be completed with a strong limitation in order not to be abused by certain parties. The enforcement of the Perppu is also expected to be supported by technological advancement aspects together with the good capability of banking's Information and Technology (IT) in order that the security in implementing this Perppu can be guaranteed. Through the implementation of this Perppu, the customers' data will become transparent, open, and in line with international provisions. Besides, their data will not be easily hacked and misused; (iii) the principles of open management that make banking activities open and transparent, so no one can hide them. This means that if the Directorate General of Taxes requires the financial account information of certain bank customers, then their financial account information will be known in detail. Therefore, customers can no longer hide their banking financial information. In other words, in this cultural transformation era, people cannot avoid the existing provisions, especially banking provisions. This policy does not necessarily make the community reluctant to save money in a bank. Therefore, it is the government's duty to strengthen this policy with a system capable of preventing hacking. The negative impact of the issuance of Perppu Number 1 of 2017 on Access to Financial Information for Tax Purposes is that the community will be reluctant to go to banks and will save their money at home. This is a challenge; in other words, it becomes a consequence when it can be avoided and best solution should be provided.

\section{References}

(1) Pasal 40 ayat 1(satu) Undang-Undang Nomor 10 Tahun 1998 Tentang Perubahan atas Undang-Undang No.7 Tahun 1992 Tentang Perbankan.

(2) Jitt B.S.Gill,2003, The Nuts and Bolts of Revenue Administration Reform, hal.16.

(3) OECD,2000, Improving Access to Bank Information for Tax Purposes, Paris:OECD Publications Service,hal.19.

(4) Johny,Ibrahim,2008, Teori dan Metodologi Penelitian Hukum Normatif, Bayumedia,Surabaya, hal.282.

(5) Bismar,Nasution,Metode Penelitian Hukum Normatif dan Perbandingan Hukum, disampaikan pada dialog interaktif tentang penelitian hukum dan hasil penulisan hukum pada Majalah Akreditasi, (Fakultas Hukum USU, tgl 18 Februari, 2003),hal.2.

(6) Dapat Dilihat Pasal 22 ayat (1) Undang-Undang Dasar 1945.

(7) Maria Indrati Seprapto, 1998, Ilmu Perundang- Undangan dasar-dasar dan pembentukannya, Kanisius, Yogyakarta, hal.80.

(8) -------------------, 1998, Ilmu Perundang- Undangan dasar-dasar dan pembentukannya, Kanisius,Yogyakarta, hal.82.

(9) ------------------------, 2007, Ilmu Perundang- Undangan Proses Dan Tehknik Pembentukannya, Kanisius, Yogyakarta, hal.94.

(10) http://nasional.kompas.com/read/2017/05/17/15571911/ini. dampak.pemberlakuan.perppu.akses.informasi.keuangan ,diakses Pada Tanggal 03 Agustus 2017, Pukul.04.15 Wib.

(11) Marco Belloni, Eol and Availability of Bank Ownership, Identity and Accounting Information, dalam Exchange of Information for Tax Purpose, ed.Oliver-Christoph Gunther dan Nicole Tuchler (Vienna : Linde Verlag, 2013).hal.524.

(12) http : // nasional. kompas. com/ read/ 2017/05/17/15571911/ ini. dampak. pemberlakuan.perppu.akses.informasi.keuangn, diakses Pada Tanggal 03 Agustus 2017 Pukul $06.25 \mathrm{Wib}$.

(13) http://www.beritasatu.com/ekonomi/435259-rekening wajib-lapor-naik-dari-rp-200-juta-jadi-rp-1-miliar.html, diakses Pada Tanggal 04 Agustus 2016 Pukul 06.14 Wib.

(14) http://www.beritasatu.com/ekonomi/435259-rekeningwajib-lapor-naik-dari-rp-200-juta-jadi-rp-1-miliar.html, diakses Pada Tanggal 03 Agustus 2017,Pukul.04.20 Wib 